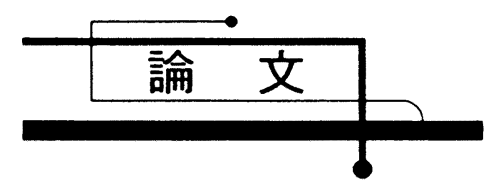

\title{
垂直円管内気液二相上昇流における気液間物質移動”
}

\section{Gas-Liquid Mass Transfer in Upward Two-Phase Flow through a Vertical Tube}

\author{
菊 地 賢 一 ${ }^{* *}$ \\ KIKUCHI Kenichi \\ 高 橋 \\ 博 \\ TAKAHASHI Hiroshi

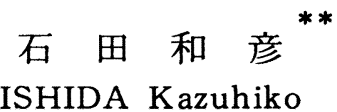

\begin{abstract}
Oxygen absorption rates into water were measured to determine volumetric mass transfer coefficients, $k_{L} a$, in bubble and slug flow regimes of gas-liquid two-phase upflow through a $0.03 \mathrm{~m}$ i.d. vertical tube. Axial local values of $k_{L} a$ decreased rapidly downstream from gas inlet. Axial averaged values of $k_{L} a$, which is denoted by $\left(\overline{k_{L} a}\right)_{x}$, were affected by gas velocity, $u_{\infty}$, liquid velocity, $u_{\omega}$, and distance from gas inlet, $z$, being correlated by the following equation:

$\left(\overline{k_{L} a}\right)_{z}=0.38 u_{C 0}^{0.69} u_{L D}^{0.33} z^{-0.27}$

Moreover, the liquid-side mass transfer coefficients, $k_{L}$, were calculated with the gas-liquid interfacial area obtained by the photographs of flow. The values of $k_{L}$ were correlated well with the energy dissipation rate, which was consistent with the eddy cell model.
\end{abstract}

Keywords: Mass Transfer, Oxygen, Gas Absorption, Two-Phase Flow, Tube Reactor

\section{1. 舶 言}

円管内気液二相流は、エアーリフト型気泡 塔や二重管式気泡塔などの気液接触装置の管 内に見られるほか、単独の管型気液接触装置 としても、液ガス流量比が大幅に変えられる、 供給エネルギーに比して接触効率がよい、ス ケールアップが容易であるなどの特長を有す るため、古くから多くの研究が行われてきた。 それらの中で、気液間物質移動に関する研究 はまず水平管を用いて行われ、1973年までの 研究は、Kasturi and Stepanek[1]により紹 介されている。それ以降では、Ziegler et al. $[3,4]$ の管型発酵器に関する研究、Zahn et al.[5]、Hatate et al.[6]らの酸素の吸収に 関する研究が見られる。一方、垂直管を用い た研究は比較的新しく、Kress and Keyes [7]をはじめとして近年多く行われているが、 対象としている流動領域はスラグ流 $[8,9]$ や アニュラー流 $[1,2,10-12]$ ようにガス速度 の高い領域のものが多く、ガス速度の低い気 泡流を含む領域を対象としたものは、Kress and Keyes[7], Ziegler et al.[3]とToda et al.[13]のものしか見あたらない。また、そ れらの実験条件も限られている。今後、円管

* 1995.1.23 受付

** 秋田大学鉱山学部物質工学科 $\mathbf{T} 010$ 秋田市手形学園町 1 の 1

TEL(0188)33-5261 FAX (0188)37-0404 
内気液二相流を気液接触装置として広く応用 して行くためには、この領域の研究の蓄積が 不可欠であろう。

本研究では、このような観点から、垂直円 管内気液二相流において気泡流からスラグ流 にわたる領域における酸素ガスの水への吸収 速度を測定することにより気液間物質移動容 量係数を求め、容量係数に与える液速度、ガ ス速度などの影響を調べ、容量係数の相関式 を提出する。また別に写真撮影法により気液 間接触面積を求めることにより夜側物質移動 係数を分離し、既往の相関式と比較する。

\section{2. 実験装置及び方法}

実験装置の概要をFig. 1 亿示す。垂直円管 本体は内径 $3.0 \mathrm{~cm}$ 、長さ $8.60 \mathrm{~m}$ の透明アクリ

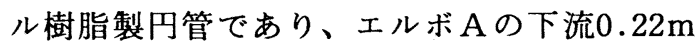
の位置にはガスの供給口が設けられている。 ガス分散器は直径 $0.3 \mathrm{~mm} \phi$ の小孔を同一円 周上に等間隔で16個開けたものである。また、 ガスの供給位置の下流 $2.00 \mathrm{~m}$ 及び $5.00 \mathrm{~m}$ には

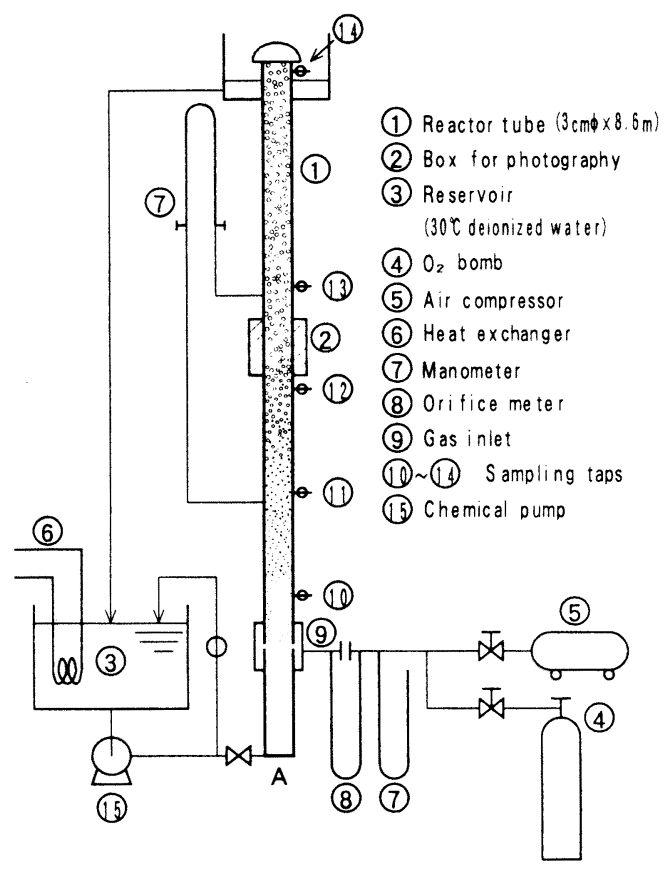

Fig. 1 Schematic diagram of experimental apparatus.
圧力測定用タップ、0.70，2.25，3.75，5.25， $8.35 \mathrm{~m}$ の各位置には溶液採取用タップを設け てある。

気液二相流の流動状態の測定は写真撮影法 により行った。すなわち、夜、ガスの速度が 定常に達したあと、ガス吹き込み口の下流 4.14 mに設けた撮影用ボックスにストロボ光を照 射し、流れ軸を含む断面を写真撮影した。得 られた断面に存在するすべての気泡及びスラ グを回転楕円体に近似し、それぞれの気液界 面積、及び体積を求めた。測定個数は、一つ の実験条件について500-1000個とした。

ガス吸収の実験は、まず $30^{\circ} \mathrm{C}$ の脱塩水を循 環させコンプレッサーにより空気を吹き込み、 溶液中の着目ガス成分の濃度を低く調整する。 次に、ガスを純酸素に切り替え、吸収実験を 開始する。ガスを切り替えた後は溶液を循環 させず全量採取してその重量から液速度を計 算した。また、反応管の入り口、出口、流れ 方向の 5 点のタップから溶液を採取し、溶存 酸素の濃度を求めた。溶存酸素の分析はウイ ンクラー・アジ化ナトリウム変法 (JIS K0101-1986)によった。

物質移動容量係数の計算は以下のようにし て行った。先ず、反応管内の流れは栓流であ り、また気体のホールドアップは流れ方向で 一定、さらにガスの吸収速度は液境膜内払散 律速と仮定し、液中の溶存酸素に関して物質 収支をとると次式が得られる。

$$
u_{L O}(d C / d z)=k_{L} a\left(C^{*}-C\right)
$$

式中の飽和濃度 $C^{*}$ は、管内の圧力が流れ方 向に直線的に変化するとし、ヘンリ一の法則 が成り立つとすれば式(2)のよ5に表される。

$$
C^{*}=H p_{1}+H\left(p_{2}-p_{1}\right) z / z_{T}
$$

実験から得られた流れ方向の濃度分布にスム一 スカーブを引き、それを微分して任意の位置 における $(d C / d z)$ を求め、式(1)、（2）を用い て物質移動容量係数の局所值を算出した。な お、酸素のヘンリー定数 Hとしては、 $11.7 \mathrm{~mol} /$ $\mathrm{m}^{3} \mathrm{MPa}\left(30^{\circ} \mathrm{C}\right)[14]$ を用いた。 
また、 $k_{L} a$ 局所值をもとに反応器入口か ら距離 $z$ の位置までの平均の物質移動容量係 数 $\left(\overline{k_{L} a}\right)_{z}$ を算出した。

$$
\left(\overline{k_{L} a}\right)_{z}=(1 / z) \int_{0}^{z} k_{L} a d z
$$

\section{3. 実験結果及び考察}

\section{1 流動領域及び圧力損失}

Fig. 2 の流動領域図中に本実験範囲を示す。 図中の破線は気泡流からスラグ流への遷移を 表し、空気一水系二相流に関する著者らの前 報 $[15]$ で求められたものであり、本酸素一水 系の場合もこの線の前後で遷移が見られた。 Photo 1 には、液速度を $1.0 \mathrm{~m} / \mathrm{s}$ としガス速 度を0.04-0.24m/sと変えた場合の流れの撮 影結果の一例を示す。低ガス速度では気泡流 なのに対し、0.18m/sではスラグが生じ始め、 $0.24 \mathrm{~m} / \mathrm{s}$ ではスラグ流になっていることが分 かる。

管内の圧力損失は全実験について圧力タッ プからのマノメータにより測定したが、その 值は都田らの式[16]による推算值とほとんど

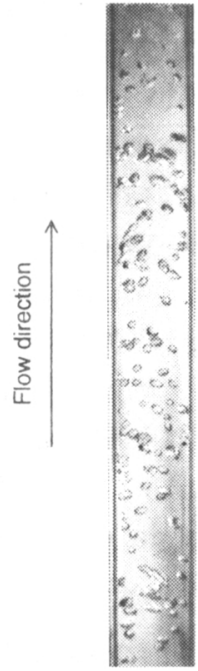

$\mathrm{u}_{\mathrm{GO}}[\mathrm{m} / \mathrm{s}] \quad 0.04$

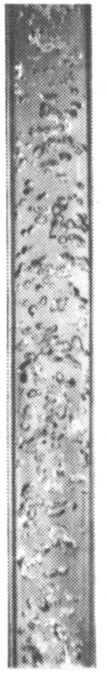

0.10

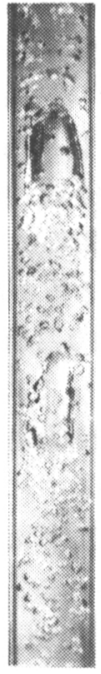

0.18

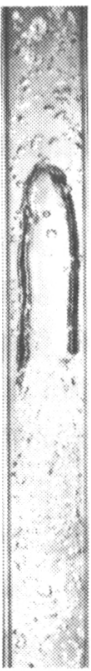

0.24
Photo 1 Typical gas-liquid upward flow $\left(u_{L O}=1.0 \mathrm{~m} / \mathrm{s}, z=4.14 \mathrm{~m}\right)$.

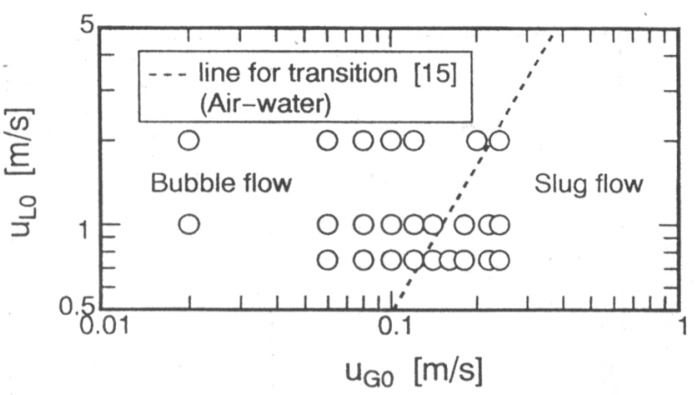

Fig. 2 Flow regime map and experimental conditions.

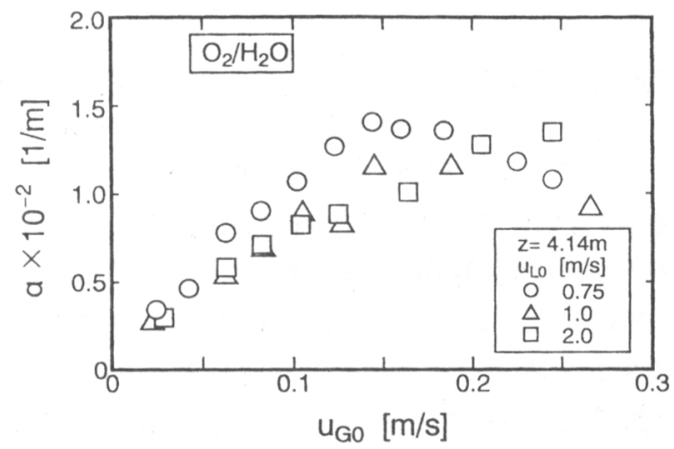

Fig. 3 Effect of gas velocity on gas-liquid interfacial area.

一致した。気体のホールドアップ $e_{G}$ は、本 報とほぼ同一の実験装置を用いて締切法によ り測定した結果、赤川[17]の式に一致するこ とを確認しており［20］、後に述べる種々の計 算の際には赤川の式による推算値を用いた。

\section{2 気液界面積}

写真撮影法により求めた気液界面積 $a$ の例 をFig. 3 に示す。これらはガス入口から4.14 $\mathrm{m}$ に打ける局所值である。液速度 $u_{L 0}=0.75$ $\mathrm{m} / \mathrm{s}$ の場合、 $\boldsymbol{a}$ はガス速度 $u_{G 0}$ が高くなるに つれて直線的に増加して行くが、 $u_{G 0}=0.15$ $\mathrm{m} / \mathrm{s}$ あたりから減少する。これはこのガス速 度付近からスラグが生じるためであり、0.15 $\mathrm{m} / \mathrm{s}$ は流れが気泡流からスラグ流に転じる臨 界速度といえる。この臨界速度は液速度が高 くなるにつれて高くなり、Fig. 2 の流動領域 

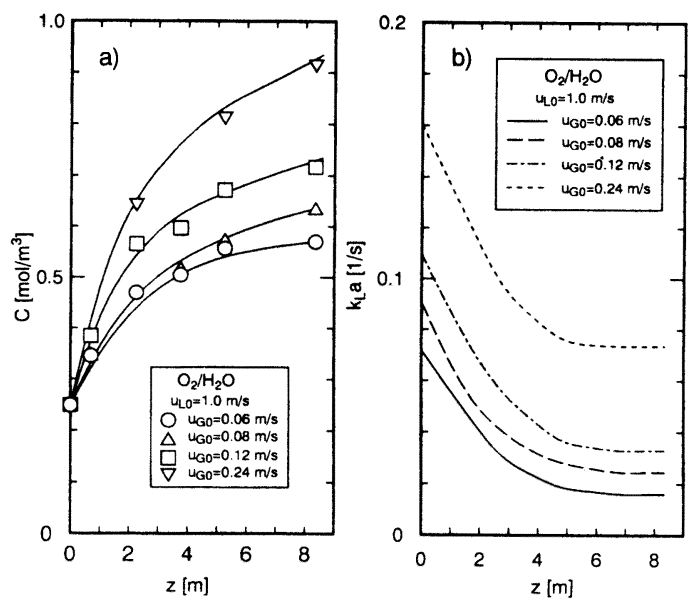

Fig. 4 Profiles of (a) oxygen concentration and (b) volumetric mass transfer coefficients in reactor tube.

図中の破線が表す速度とほぼ一致した。

\section{3 物質移動容量係数}

Fig. 4-a)に、ガス吸収実験における液中 ガス成分濃度の円管流れ力向分布を示す。溶 存酸素の濃度はガス入り口から $4 \mathrm{~m}$ ぼの間 に急激に増加し、それ以降は緩やかに增加し ている。また濃度はガス速度が高くなるにつ れて高くなる。Fig. 4-b)には、これらの濃 度分布をもとに算出した $k_{L} a$ の分布を示す。 $k_{L} a$ は反応管入り口から急激に減少するが、 $4 \mathrm{~m}$ ほどで咸少は緩やかになり、しだいにほ ぼ一定值に近づくように見える。流れ方向に $k_{L} a$ が変化する同様な傾向は、Toda et al. [13]の炭酸ガスの吸収や只木ら[29]の炭酸ガ スの放散でも報告されている。これらの $k_{L} a$ の変化の原因としては、気泡の合体による気 液界面積 $a$ の減少、あるいは水中の微量污染 物質の気液界面への吸着による $k_{L}$ の減少 [29] などが考えられる。垂直円管内上昇流の助走 区間で気泡の急激な合体が生じることは畠山 ら[28]の流動実験により明らかにされており、 また本実験のように脱塩水を用いた場合気泡 の合体が進み易いことも一般的に知られてい る。しかしながら、污染物質の吸着により吸

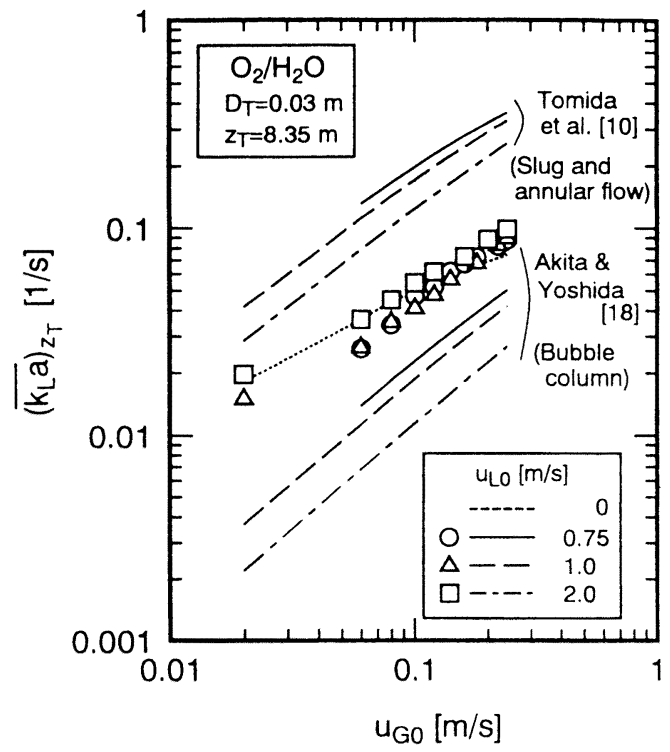

Fig. 5 Effects of gas and liquid velocities on $\overline{\left(k_{L} a\right)} z_{T}$ for oxygen absorption.

収速度が変化する現象についての詳細な研究 は見あたらない。本実験結果はこのよ5な因 子の複合効果と考えられるが、詳細は不明で ある。

Fig. 4-b)の結果を用いると、ガスの入口 から出口 $\left(z_{T}=8.35 \mathrm{~m}\right)$ までの平均の物質移動 容量係数 $\left(\overline{k_{L} a}\right)_{z_{T}}$ を式(3) で計算できる。 Fig. 5 は $\left(\overline{k_{L} a}\right) z_{T}$ を、液・ガス速度をパラメータ として示したものである。 $\left(\overline{k_{L} a}\right)_{T}$ はガス速 度あるいは液速度が高くなるにつれて増加す る。Fig. 2 によれば本実験条件の大半は気泡

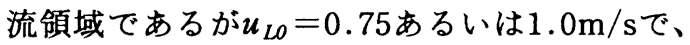
かつ $u_{G 0}=0.15 \mathrm{~m} / \mathrm{s}$ 程度以上ではスラグ流領 域にはいっている。しかし、 $\left(\overline{k_{L} a}\right)_{z_{T}}$ はをそ れらの巨視的流動状態の影響は明確には見ら れない。図中には既往の実験式による推算値 も合わせて示してある。Tomida et al.[10] の式は次のように表されるが、

$$
\begin{aligned}
\overline{k_{L} a}= & 10^{-4}(\Delta p / \Delta z)_{f} D_{T} \rho^{0.5} D^{0.5} e_{G} \mu^{-1.5} \\
& \times\left(\mu / \mu_{W}\right)^{1.7}\left(\sigma / \sigma_{W}\right)^{0.5}
\end{aligned}
$$

これはスラグからアニュラ一流にわたる高速 度領域で得られものであり、実験值より数倍 
大きい値を示しているのもこの理由によるも のと考えられる。一方、Akita \& Yoshida [18]の式は次のように表される。

$$
\begin{aligned}
\overline{k_{L} a} D_{T}^{2} / D= & 0.6(\nu / D)^{0.50}\left(g D_{T}^{2} \rho / \sigma\right)^{0.62} \\
& \left(g D_{T}{ }^{3} / \nu^{2}\right)^{0.31} e_{G}^{1.1}
\end{aligned}
$$

この式は、気泡塔に関する式であるが、流動 に関係するパラメータがガスホールドアップ $e_{G}$ のみであることから、本実験の液・ガス 速度から赤川 $[17]$ の式を用いて $e_{G}$ を計算し、 その值を代入することにより容量係数を求め た。ただし、 $u_{L O}=0$ の $e_{G}$ は気泡塔に関する Akita \& Yoshida[18]の式により求めた。計 算値は、 $u_{L O}=0$ の場合にほほ夷験值と一致 しているが、他の值は実験値より数分の 1 小 さい。すなわち、ガスホールドアップが同じ 場合、容量係数は気液二相流より気泡塔の方 が小さい。これは、気泡荅の場合は液速度が ゼロのな液の逆混合が激しく気泡の合体が 起こり易いのに対し、二相流の場合にはFig. 2 のよ5に気泡流領域での実験のため気泡塔 ほどの合体が起こらなかったことによるもの と考えられる。

Fig. 5 には $z=0-z_{T}$ 間の平均物質移動容量 係数を示したが、容量係数はFig. 4-b)に見 られるよ5に流れ方向に分布を示しているか ら、任意の距離 $z$ までの平均物質移動容量係 数 $\left(\overline{k_{L} a}\right)_{2}$ が計算できる。それを全実験值に ついて計算し整理した結果、式(6)が得られ た。

$$
\left(\overline{k_{L} a}\right)_{z}=0.38 u_{C 0^{0.69}} u_{L 0}^{0.33} z^{-0.27}
$$

さて、これまでの相関はいずれむ、液速度・ ガス速度をパラメータに用いてきたが、以下 のように、管内に加えられた動力から計算さ れるエネルギー消散速度をパラメータとして

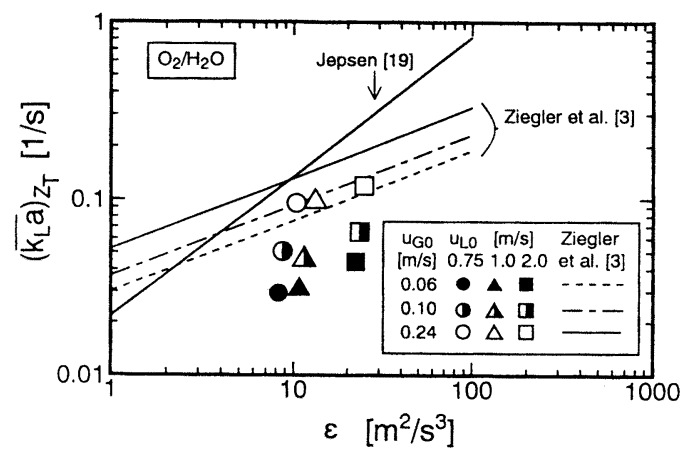

Fig. 6 Correlation of $\left(\overline{k_{L} a}\right)_{z_{T}}$ with energy dissipation rate for oxygen absorption.

用いる相関方法も行われている。例えば、 Jepsen[19]は、水平管による酸素ガスの吸収 実験を行い $\varepsilon$ の大き值に対して次式を提出 している。式中の $\varepsilon$ は、液体単位質量当たり のエネルギー消散速度である゙。

$$
\overline{k_{L} a}=9.29 \varepsilon^{0.79} \rho^{0.79} D^{0.50} \sigma^{0.50} \mu^{0.05}
$$

また、Ziegler et al.[3]は水平及び垂直管か らなる矩形のループ式発酵器を用いて酸素の 吸収実験を行い、次式を得ている*)。

$$
\overline{k_{L} a}=5.87 \times 10^{-3} \varepsilon^{0.4} \rho^{0.4} u_{C 0^{0.4}}
$$

本吸収実験の結果を $\varepsilon$ を用いて計算し、式(7), （8）と比較したのがFig. 6 である。ただし、 $\varepsilon$ の計算には次式(9)[20]を用いた。

$$
\begin{aligned}
\varepsilon= & u_{G 0} g-e_{G} u_{L o} g /\left(1-e_{G}\right) \\
& +(\Delta p / \Delta z)_{f}\left(u_{L o}+u_{G o}\right) /\left(1-e_{G}\right) \rho
\end{aligned}
$$

図によれば、ガス速度が高い場合の実験結果 はZiegler et al.[3]の式に近い值を示すが、 全体的には推算值よりかなり低い値を示して いる。これは、文献値のガス速度が本研究よ りかなり高いことと、水平管と垂直管では気

*) Jepsen[19], Ziegler et al.[3]の原著における よく用いられる液体単位質量当たりの定義に換算した。 
泡の流動様式がかなり異なることによるもの と考えられる。

\section{4 物質移動係数}

吸収実験で得られた $z=4.14 \mathrm{~m}$ の位置にお ける物質移動容量係数 $\overline{k_{L} a}$ を気液界面積 $a$ で 割ることにより、物質移動係数 $k_{L}$ を分離し た。流動領域は気泡流領域に限定した。得ら れた結果をFig. 7-b)に示す。なお、Fig. 7ー a) は写真撮影法で得た気泡径 $D_{B}$ (Sauter diameter)である。気泡径分布の標準偏差は20 $-25 \%$ 範囲であり、一例として、 $u_{L 0}=2.0$ $\mathrm{m} / \mathrm{s}$ の場合の偏差を図中に示した。図によれ ば、物質移動係数は、低ガス速度を除き、ガ ス速度が高くなるにつれて徐々に增加する傾 向にある。また、液速度が高くなっても增加 する。図中の実線は、Calderbank \& MooYoung[21]の次式による推算值である。

$$
D_{B} \geqq 2.5 \mathrm{~mm}, \quad k_{L}=0.42 S c^{-1 / 2}\left(\Delta \rho \mu g / \rho^{2}\right)^{1 / 3}
$$
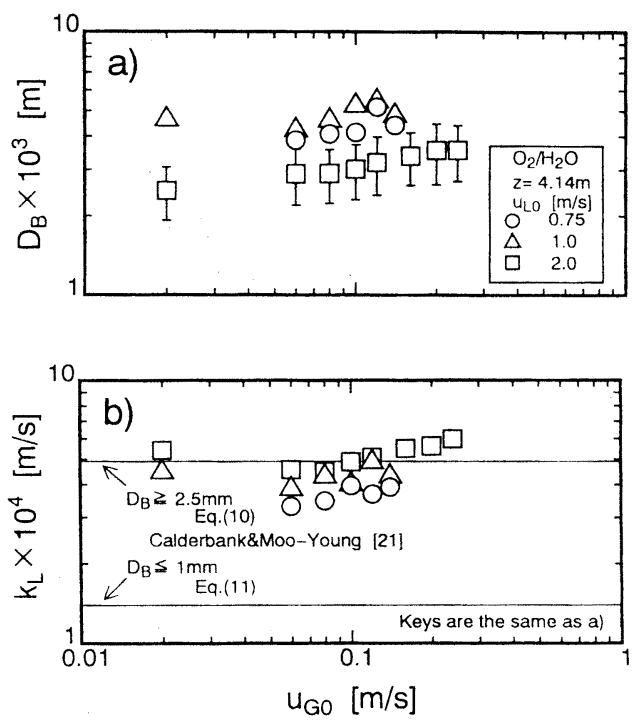

Fig. 7 Effects of gas and liquid velocities on (a)Sauter mean bubble diameter and (b)liquid-side mass transfer coefficient for oxygen absorption.

$$
D_{B} \leqq 1.0 \mathrm{~mm}, \quad k_{L}=0.31 S c^{-2 / 3}\left(\Delta \rho \mu \mathrm{g} / \rho^{2}\right)^{1 / 3}
$$

本実験結果は、気泡径が $2.5 \mathrm{~mm}$ 以上に適用 できる式(10)の值にほぼ一致しており、気泡 径の実験值もほぼこの条件を満足している。 また、気泡径が小さい方が、物質移動係数が 大きくなっているが、この傾向は静止流体中 を上昇する単一気泡に関するMotargemi \& Jameson[22]の実験結果と一致している。

気液間物質移動における液側物質移動につ いての理論や実験式は古くから提出されてお り、以降ではその代表的なものと本実験結果 を比較した。まず、Fig. 7-a)の気泡径 $D_{B}$ を もとに、Motargemi \& Jameson[22]の結果 より静止液体中の気泡の上昇速度 $u_{B}$ を推算 して気液の接触時間 $t_{e}\left(=D_{B} / u_{B}\right)$ を求め、そ れらの值を用いてHigbie[23]による非定常 ガス吸収理論の次式から $k_{L}$ を計算した。

$$
k_{L}=2\left(D / \pi t_{e}\right)^{1 / 2}
$$

得られた結果は、 $\pm 30 \%$ の範囲で実験值と一 致した。したがって、本実験範囲における気 泡からの物質移動は静止液体を上昇する気泡 からの物質移動とオーダ一的に同程度と考え られる。

$$
\text { 次に、パワーグループ }\left(\varepsilon^{1 / 3} D_{B}^{4 / 3} / \nu\right) \text { を用 }
$$
いた相関をFig. 8 に示す。実線は、エディセ ルモデル (eddy cell model)として有名な Lamont \& Scott[25]によるもの（式(13)) とそれを修正したRisse et al.[26]によるも の（式(14)）、さらにこの相関方法では初期 のものとして知られているCalderbank \& MooYoung[21]によるもの（式(15)）と最近の 著者ら[27]によるもの（式(16)）である。

$$
\begin{aligned}
& k_{L}=0.4\left(\begin{array}{ll}
\varepsilon & \nu
\end{array}\right)^{1 / 4} S c^{-1 / 2} \\
& k_{L}=0.2\left(\begin{array}{lll}
\varepsilon & \nu
\end{array}\right)^{1 / 4} S c^{-1 / 2} \\
& k_{L}=0.13\left(\begin{array}{lll}
\varepsilon & \nu
\end{array}\right)^{1 / 4} S c^{-2 / 3}
\end{aligned}
$$




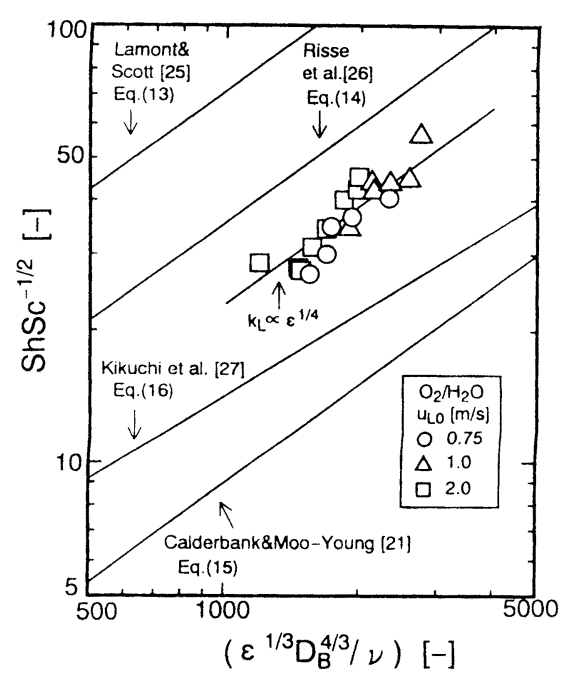

Fig. 8 Correlations of $S h S c^{-1 / 2}$ with and specific power group for oxygen absorption $(S c=286)$.

$$
S h=2+0.47\left(\varepsilon^{1 / 3} D_{B}^{4 / 3} / \nu\right)^{0.63} S c^{1 / 3}
$$

実験結果は、式(9)によりをを計算してプロッ トしたものである。図によれば、実験值は液 速度によらずほぼ一致しており、その傾きか ら、 $k_{L}$ はエネルギー消散速度のほぼ $1 / 4$ 乗に 依存しており、エディセルモデルから予想さ れる結果に一致した。しかしその絶対值は Lamont \& Scottの式より小さく、Risse et al.の式に近い值を示した。一方、Kikuchi et al. PCalderbank \& Moo-Youngの式より は大きな值を示した。これは、これらの 2 式 が固液間の物質移動を対象としたものであり、 気液界面のように物質移動界面が滑る場合の 物質移動の説明には不適当なためと考えられ る。

\section{4. 結 言}

垂直円管内気液二相流の気泡流及びスラグ 流領域において酸素の脱塩水への吸収実験を 行い、次の結果を得た。

物質移動容量係数は、ガスの入りロから下 流に進むにつれて急激に減少した。流れ方向
の平均の物質移動容量係数は、ガス速度、液 速度、円管の長さに影響を受け、式(6)で良 好に相関づけられた。

夜側物質移動係数は、低ガス速度を除き、 ガス速度及び夜速度が高くなるにつれて増加 した。実験值はエネルギー消散速度によって 相関でき、相関式の傾きはLamont and Scottらのエディセルモデルの傾きに一致し た。

\section{謝 辞}

佐藤幸保技官、学生の菅原 純、民部将二 の各氏には実験の面で助力を得た。ここに記 して謝意を表します。

\section{Nomenclature}

$a$ : gas-liquid interfacial area per $[1 / \mathrm{m}]$ unit volume of tube

C : concentation $\left[\mathrm{mol} / \mathrm{m}^{3}\right]$

$C^{*} \quad$ : saturated concentration $\quad\left[\mathrm{mol} / \mathrm{m}^{3}\right]$

$D$ : diffusivity $\left[\mathrm{m}^{2} / \mathrm{s}\right]$

$D_{B} \quad$ : Sauter mean bubble diameter [m]

$D_{T}$ : tube diameter [m]

$\boldsymbol{e}_{G} \quad$ : gas holdup [-]

g : gravitational acceleration $\left[\mathrm{m} / \mathrm{s}^{2}\right]$

$H$ : Henry constant $\quad\left[\mathrm{mol} / \mathrm{m}^{3} \mathrm{~Pa}\right]$

$k_{L} \quad:$ liquid-side mass transfer coefficient

$k_{L} a$ : volumetric mass transfer coefficient

$\left(\overline{k_{L} a}\right)_{2}:$ axially averaged $(z=0 \sim z)$ value of $k_{L} a$

$\left(\overline{k_{L} a}\right)_{z_{T}}$ : axially averaged $\left(z=0 \sim z_{T}\right)$ value of

$$
k_{L} a \quad[1 / \mathrm{s}]
$$

$p_{1}:$ pressure at reactor $\operatorname{inlet}(z=0) \quad[\mathrm{Pa}]$

$p_{2} \quad$ : pressure at reactor outlet $\left(z=z_{T}\right)[\mathrm{Pa}]$

$(\Delta p / \Delta z)_{\mathrm{f}}$ : pressure gradient $[\mathrm{Pa} / \mathrm{m}]$

$\operatorname{Re}_{B} \quad$ : Reynolds number $\left(=D_{B} u_{B} / \nu\right) \quad[-]$

Sc : Schmidt number $(=\nu / D)$ [-]

$S h$ : Sherwood number $\left(=k_{L} D_{B} / D\right) \quad[-]$

$t_{\text {e }}$ : gas-liquid contact time [s]

$u_{B}$ : relative velocity of bubble to liquid

$[\mathrm{m} / \mathrm{s}]$

$u_{G O}:$ superficial velocity of gas $\quad[\mathrm{m} / \mathrm{s}]$

$u_{L O}$ : superficial velocity of liquid $[\mathrm{m} / \mathrm{s}]$

$z$ : distance from gas inlet [m]

$z_{T} \quad$ : distance from gas inlet to last sampling$\operatorname{tap}(=8.35 \mathrm{~m}) \quad[\mathrm{m}]$

\section{(Greek letters)}

$\varepsilon \quad$ : energy dissipation rate per unit mass of liquid $\left[\mathrm{m}^{2} / \mathrm{s}^{3}\right]$ 
$\mu \quad:$ viscosity of liquid $\quad[\mathrm{Pa} \quad \mathrm{s}]$

$\mu_{\mathrm{w}} \quad$ : viscocity of water [Pa

$\nu \quad$ : kinematic viscosity of liquid $\left[\mathrm{m}^{2} / \mathrm{s}\right]$

$\rho \quad:$ density of liquid $\left[\mathrm{kg} / \mathrm{m}^{3}\right]$

$\Delta \rho:$ defference in density between liquid and gas $\left[\mathrm{kg} / \mathrm{m}^{3}\right]$

$\sigma \quad$ : surface tension of liquid $[\mathrm{N} / \mathrm{m}]$

$\sigma_{\mathrm{W}}:$ surface tension of water $[\mathrm{N} / \mathrm{m}]$

\section{参考文献}

[ 1 ] Kasturi, G.and J.B.Stepanek, Chem.Eng. Sci. , Vol.29, 1849-1856(1974).

[2] Shilimkan, R.V.and J.B.Stepanek, Chem . Eng.Sci. , Vol.32,1397-1400(1977).

[ 3 ] Ziegler,H., D. Meister and I.J.Dunn, Biotech.Bioeng., Vol. 19,507-525(1977).

[4] Ziegler,H.,I.J.Dunn and J.R.Bourne, Biotech.Bioeng., Vol.22,1613-1635(1980).

[5] Zahn, A., et al., Coll.Czech.Chem . Commun., Vol.50,745-756(1985).

[6] Hatate, Y.,et al., Proc. The Asian Conf. on Fluidized Bed and Three-Phase Reactors, Tokyo, Japan,480-488(1991).

[ 7 ] Kress, T.S. and J.J.Keyes, Jr., Chem . Eng. Sci. , Vol.28, 1809-1823(1973).

[8] Niranjan, K., et al., Chem.Eng.Sci., Vol. 43,1247-1252(1988).

[9] Sena Esteves, M.T.and J.R.F.Guedes De Carvalho, Chem.Eng. Sci. , Vol.48, 34973506 (1993).

[10] Tomida, T., M. Yoshida and T. Okazaki, J. Chem.Eng.Jpn., Vol.9, No.6,464-468(1976).

[11] Tomida, T.,F.Yusa and T.Okazaki, Chem. Eng.J., Vol.16,81-88(1978).

[12] Tomida, T., Ind.Eng.Chem.Res., Vol.26, 1472-1475(1987).

[13] Toda,M.,et al.,Proc.The Intl.Conf.on
Multiphase Flows' 91-Tsukuba, 2, 225-228

(1991).

[14] 化学工学会編、化学工学便臨第 5 版、丸善、 東京 (1988).

[15] 菊地賢一ほか、化学工学論文集、Vol.21, No. 4,832-835(1995).

[16] 都田昌之ほか、化学工学論文集、Vol.8, No. 4,380-386(1982).

[17] 赤川浩爾、日本機械学会論文集、Vol.23, No. 128, 285-291 (1957).

[18] Akita, K. and F. Yoshida, Ind.Eng. Chem., Process. Des. Dev., Vol.12,76-80 (1973).

[19] Jepsen,J.C., A.I.Ch.E.J., Vol.16, No.5, 705-711 (1970).

[20］菊地賢一ほか、混相流、Vol.4, No.1,21-31 (1990)

[21] Calderbank, P.H.and M.B.Moo-Young, Chem.Eng.Sci. , Vol.16, Nos. 1\&2, 39-54 (1961).

[22] Motarjemi, M.and G.J.Jameson, Chem . Eng.Sci. , Vol.33, 1415-1423(1978).

[23] Higbie, R. ,Trans. Am.Inst.Chem.Engrs., Vol.31,365-389(1935).

[24] Ranz,W.E.and W.R.Marshall, Chem. Eng.Prog., Vol.48, No.3,141-146,173-180 (1952).

[25] Lamont, J.C. and D.S.Scott, A.I.Ch.E. J. , Vol.16, No.4,513-519(1970).

[26] Risse,F.U., P.Weiland and U.Onken, Ger.Chem.Eng., Vol.9,107-117(1986).

[27] Kikuchi, K., et al.,J.Chem.Eng.Jpn., Vol. 20, No.2,134-140(1987).

[28］皇山信夫ほか、日本鉱業会誌、Vol.100,No. $1157,575-580(1984)$.

[29]只木楨力、前田四郎、化学工学、Vol.27, 808-814 (1963). 